\title{
Development of a SCAR marker and a semi-selective medium for specific quantification of Pichia anomala strain K on apple fruit surfaces
}

\author{
D. De Clercq ${ }^{1}$, S. Cognet, M. Pujol, P. Lepoivre, M.H. Jijakli* \\ Plant Pathology Unit, Faculté Universitaire des Sciences Agronomiques de Gembloux, Passage des Déportés 2, 5030 Gembloux, Belgium
}

Received 21 August 2002; accepted 6 March 2003

\begin{abstract}
A washing procedure for apple fruit surfaces, and a semi-selective medium, were developed to assess the population dynamics of Pichia anomala strain K, a biocontrol agent against Botrytis cinerea and Penicillium expansum on fruit. The application of this plating technique allowed more than $99 \%$ recovery of strain K population on treated apples (by dipping them in a suspension of strain $\mathrm{K}$ at $10^{7} \mathrm{cfu} / \mathrm{ml}$ ). A strain $\mathrm{K}$ population decline of $51 \%$ was observed after 14 days of cold storage. To overcome the lack of specificity of the plating method, the RAPD technique was applied to a collection of 11 strains of $P$. anomala, including strain K. RAPD amplification with primer OPN13 produced a reproducible fragment of about $2000 \mathrm{bp}$, which was specific for strain $\mathrm{K}$. Based on this DNA fragment, a SCAR marker of $262 \mathrm{bp}$ was amplified with K1 and K2 primers for strain K as confirmed by Southern blot analysis, and was negative for a collection of 30 yeast strains including 21 P. anomala strains. A mixed monitoring method was developed and consisted of a combined plating technique on a semi-selective medium followed by a direct strain K-SCAR amplification without DNA extraction, on released DNA from resuspended white yeast colonies. This method was used on apples treated with strain $\mathrm{K}\left(10^{7} \mathrm{cfu} / \mathrm{ml}\right)$ produced in Petri dishes, or in a bio-reactor (as a dry powder) with or without additives ( $2 \% \mathrm{CaCl}_{2}$ and $0.2 \%$ beta-1,3-glucan) previously identified to enhance the strain $\mathrm{K}$ efficacy against $B$. cinerea. The percentages of recovered white colonies identified as strain $\mathrm{K}$ with the use of the specific SCAR marker ranged between 91 and $100 \%$. The population densities reached similar levels of $1.1 \times 10^{4}$ and $0.7 \times 10^{4} \mathrm{cfu} / \mathrm{cm}^{2}$ on apples, $24 \mathrm{~h}$ after treatment with the powder formulation, without and with the stimulating agents, respectively. In contrast, a stimulating effect of glucan and $\mathrm{CaCl}_{2}$ on strain $\mathrm{K}$ population density was observed in apples treated with fresh cells produced in Petri dishes. Whatever the treatment, population densities diminished 1 week after application in cold storage conditions.
\end{abstract}

(C) 2003 Elsevier B.V. All rights reserved.

Keywords: Biological control; Botrytis cinerea; Penicillium expansum; Monitoring; RAPD

* Corresponding author. Tel.: +32-8-162-2431; fax: +32-8-161-0126.

E-mail address: jijakli.h@fsagx.ac.be (M.H. Jijakli).

${ }^{1}$ Present address: KULeuven, Laboratory for Phytopathology and Plant Protection, De Croylaan 42, 3001 Heverlee, Belgium. 


\section{Introduction}

Botrytis cinerea Pers: Fr and Penicillium expansum Link., the causal agents of grey and blue molds respectively, are two of the most devastating pathogens on harvested apples. Their control is still primarily based on chemical treatments. However, there is a need to develop alternative control methods because of the appearance of fungicide resistant pathogen strains (Franclet, 1994), the impending deregistration of fungicides (Wellings, 1996), and health and environmental public concern. In this context, Jijakli and Lepoivre (1998) previously demonstrated that Pichia anomala (Hansen) Kurtzman strain $\mathrm{K}$ exhibits a high and reliable biocontrol activity against grey and blue molds on 'Golden Delicious' apples.

Besides knowledge of the mechanisms of action (Grevesse et al., 1998), monitoring tools need to be developed to study the ecological fitness of $P$. anomala strain $\mathrm{K}$ after treatment on apples. Because the protective effect of strain $\mathrm{K}$ seems to be closely related to its colonisation on the apple surface (Jijakli et al., 1999), assessment of strain K population dynamics will help to interpret and predict biocontrol efficacy in relation to modality of application, formulation and environmental conditions. In addition, identification and quantification of strain $\mathrm{K}$ during and after its mass production and formulation are a prerequisite to establish a quality control procedure for the biofungicide.

Monitoring strain $\mathrm{K}$ requires its unambiguous differentiation among the resident micro-flora (including yeast belonging to the same species) and its quantification on the surface of apples. The shortcomings of the biochemical-based typing methods, which depend on phenotypic expression, and the lack of morphological distinction among similar yeasts on Petri dishes, led to the development of more specific identification methods based on DNA sequences. DNA markers minimise the difficulty of typeability and lack of reproducibility common in the use of phenotypic-based methods (Olive and Bean, 1999).

A DNA marker can be obtained by gene insertion (Chand-Goyal et al., 1999). This type of DNA marker involves genetic modification of the organism, which would introduce difficulties for further practical applications. Moreover, the application of this method requires that wild type and engineered strains have the same fitness properties in situ, which is still difficult to demonstrate. In contrast, identification of a DNA-based typing on natural polymorphisms overcomes these problems. Olive and Bean (1999) reviewed the methods for identification of a natural marker. Among them, the Random Amplified Polymorphic DNA (RAPD; Williams et al., 1990) fingerprinting method has been widely used because of its simplicity and its capacity to differentiate numerous microorganisms (Arisan-Atac et al., 1995; Thanos et al., 1996; Batinic et al., 1998). However, the inconvenience of RAPD is its lack of reproducibility due to the low-stringency amplification conditions. Therefore, RAPD markers are transformed into Sequence Characterised Amplified Region (SCAR) markers which allow a reproducible amplification of one single fragment (Abassi et al., 1999).

The aim of this work was the identification of a specific SCAR marker for $P$. anomala strain $\mathrm{K}$ by using the RAPD fingerprinting method, followed by the development of a monitoring method combining dilution plating on a semi-selective medium and strain-specific identification of colony forming units with the SCAR marker.

\section{Materials and methods}

\subsection{Yeast isolates and DNA extraction}

P. anomala strain $\mathrm{K}$ isolated from the surface of 'Golden Delicious' apples (Jijakli and Lepoivre, 1993), was identified by the Centraalbureau voor Schimmelculturen (Utrecht, The Netherlands). The other strains of $P$. anomala (Table 1) were obtained from the Mycothèque de l'Université Catholique de Louvain (Louvain-la-Neuve, Belgium), from the Central Research Laboratory of Tokyo (Tokyo, Japan), and from Johan Schnürer (Swedish University of Agricultural Sciences, Uppsala, Sweden). Strains of Candida oleophila, Candida sake, Debaryomyces hansenii and Saccharomyces cerevisiae were provided by the Plant 
Table 1

Origin and source of yeast strains

\begin{tabular}{|c|c|c|c|}
\hline $\begin{array}{l}\text { Yeast spe- } \\
\text { cies }\end{array}$ & Strains & Original substrate & Source \\
\hline \multirow[t]{3}{*}{ C. oleophila } & $\mathrm{O}$ & $\begin{array}{l}\text { 'Golden Delicious' } \\
\text { apple }\end{array}$ & Plant Pathology Unit, FUSAGX (Gembloux, Belgium) \\
\hline & I-182 & Apple & Ecogen, Inc. (Langhorne, USA) \\
\hline & CBS4371 & Cider & Centraalbureau voor Schimmelculturen (Utrecht, The Netherlands) \\
\hline \multirow[t]{2}{*}{ C. sake } & CBS159 & Unknown & \\
\hline & CBS2882 & Egg yolk & \\
\hline \multirow[t]{2}{*}{ D. hansenii } & MUCL29030 & French cheese & Mycothèque de l'Université Catholique de Louvain-La-Neuve (Belgium) \\
\hline & MUCL29907 & Human skin & \\
\hline \multirow[t]{22}{*}{ P. anomala } & $\mathrm{K}^{\mathrm{a}}$ & $\begin{array}{l}\text { 'Golden Delicious' } \\
\text { apple }\end{array}$ & Plant Pathology Unit FUSAGX (Gembloux, Belgium) \\
\hline & MUCL29421 ${ }^{\mathrm{a}}$ & Unknown & Mycothèque de l’Université Catholique de Louvain-La-Neuve (Belgium) \\
\hline & MUCL29422 & Unknown & \\
\hline & MUCL29423 ${ }^{\mathrm{a}}$ & Unknown & \\
\hline & MUCL27729 & Brewery & \\
\hline & MUCL27753 ${ }^{\mathrm{a}}$ & Unknown & \\
\hline & MUCL28480 & $\begin{array}{l}\text { Ensilage of maize } \\
\text { plants }\end{array}$ & \\
\hline & MUCL30385 ${ }^{\mathrm{a}}$ & Bakery leaven & \\
\hline & MUCL20294 & Ensilage of corn & \\
\hline & $\mathrm{U}-1^{\mathrm{a}}$ & Unknown & Central Laboratory of Research (Tokyo, Japan) \\
\hline & HU- $1^{\mathrm{a}}$ & Unknown & \\
\hline & $\mathrm{J} 121$ & Cereals & $\begin{array}{l}\text { Department of Microbiology, Swedish University of Agricultural Sciences } \\
\text { (Uppsala, Sweden) }\end{array}$ \\
\hline & $\mathrm{J} 375$ & Cereals & \\
\hline & J376 & Cereals & \\
\hline & $\mathrm{J} 377$ & Cereals & \\
\hline & $\mathrm{J} 378$ & Cereals & \\
\hline & J379 & Cereals & \\
\hline & $\mathrm{J} 380$ & Cereals & \\
\hline & J381 & Cereals & \\
\hline & $\mathrm{J} 382$ & Cereals & \\
\hline & $\mathrm{J} 383$ & Cereals & \\
\hline & J384 & Cereals & \\
\hline \multirow[t]{2}{*}{ S. cerevisiae } & P4-1 & Unknown & Animal and Microbial Biology Unit, FUSAGx (Gembloux, Belgium) \\
\hline & Le382 & Unknown & \\
\hline
\end{tabular}

\footnotetext{
a Strain used for RAPD analysis.
}

Pathology Unit and the Animal and Microbial Biology Unit of the Faculté Universitaire des Sciences Agronomiques (Gembloux, Belgium), the Centraalbureau voor Schimmelculturen (Utrecht, The Netherlands), Ecogen, Inc. (Langhorne, USA), and the Mycothèque de l'Université Catholique de Louvain (Louvain-la-Neuve, Belgium). Yeast strains were cultured at $25^{\circ} \mathrm{C}$ for three successive generations on a potato dextrose agar (PDA) (E. Merck AG, Darmstadt, Germany) medium over $24 \mathrm{~h}$. Long-term storage was carried out at $-80{ }^{\circ} \mathrm{C}$ in glycerol $(25 \%)$, and on PDA medium at $4{ }^{\circ} \mathrm{C}$ for periods no longer than 6 months. Strains were subsequently cultured in YEPD (yeast extract 1\%, peptone $2 \%$, glucose $2 \%$ ) at $25{ }^{\circ} \mathrm{C}$ over $24 \mathrm{~h}$ for DNA extractions using the method described by Ausubel et al. (1987).

\subsection{Semi-selective medium assessment}

The semi-selective medium (HST-PDA) is composed of PDA supplied with $12.5 \mathrm{mg} / \mathrm{l}$ hygromycin 
B (Duchefa, Haarlem, The Netherlands), $5 \mathrm{mg} / \mathrm{l}$ Sumico (including $1.25 \mathrm{mg} / \mathrm{l}$ carbendazim, and $1.25 \mathrm{mg} / \mathrm{l}$ diethofencarb; AgrEvo, Machelen, Belgium), and $0.25 \mathrm{mg} / 1$ thiram (UCB, Brussels, Belgium).

Toxicity of the medium was firstly evaluated upon plating $2 \times 10^{2} \mathrm{cfu}$ of strain K on HST-PDA as well as on PDA (four replicates for each medium), concentration of strain $\mathrm{K}$ suspension being determined by OD measurements at $595 \mathrm{~nm}$ using a standard curve. The number of cfu was observed 2, 3, 4, and 7 days after plating.

Toxicity of the HST-PDA medium was also evaluated on strain $\mathrm{K}$ yeast cells surviving on the surface of postharvest apples. Fifteen 'Golden Delicious' apples were dipped in a water suspension containing $10^{7} \mathrm{cfu} / \mathrm{ml}$ of strain $\mathrm{K}$ and $0.85 \%$ $\mathrm{NaCl}$ for $2 \mathrm{~min}$; 15 other apples remained untreated. The total number of cells deposited on the apple surface after dipping was estimated by determining the strain $\mathrm{K}$ suspension volume used per apple. After drying at ambient temperature for $2 \mathrm{~h}$, five treated apples were washed separately in KPB buffer [0.016 $\mathrm{M} \mathrm{K}_{2} \mathrm{HPO}_{4}, 0.034 \mathrm{M} \mathrm{KH}_{2} \mathrm{PO}_{4}$ and $0.05 \%(\mathrm{w} / \mathrm{v})$ Tween $80 ; \mathrm{pH}$ 6.5] for $20 \mathrm{~min}$ on a shaking table. Two $\mathrm{ml}$ of each washing water sample were pooled and this operation was repeated to provide a second replicate. The same washing procedure was applied to untreated apples. Five-fold dilutions were subsequently plated out and the colony forming units, morphologically similar to strain $\mathrm{K}$, were counted on the solid HST-PDA media (four replicates) after 4-5 days of incubation at $25^{\circ} \mathrm{C}$. After the washing procedure, $20 \mathrm{~cm}^{2}$ of five apple epidermis were ground with a roller press in $10 \mathrm{ml}$ of the same buffer directly after strain $\mathrm{K}$ treatment and apple washing. Three ground extract samples $(100 \mu \mathrm{l})$ per apple were plated out on PDA and the colonies were counted after 4 days incubation. The remaining 20 apples were stored at $4{ }^{\circ} \mathrm{C}$ in a cold room for 14 and 58 days before being submitted to the same recovery protocol. The mean surface area of the apples was evaluated by means of a previously established linear relationship between the surface of apples and their volume measured by water displacement: Surface $\left(\mathrm{cm}^{2}\right)=0.488 \times$ Volume displaced water $(\mathrm{ml})+66.1(r=0.99)$.
To evaluate the selectivity of the medium, washing water samples of five non-treated apples were plated out on both media. After 1 week of incubation at $25^{\circ} \mathrm{C}$, colonies were visually and microscopically observed.

\subsection{RAPD and SCAR markers}

Twenty five random primers obtained from Operon Technologies Inc. (Alameda, California) were screened against extracted genomic DNA of 11 P. anomala strains (Table 1) including strain K. PCR amplification conditions consisted of an initial denaturation $\left(95^{\circ} \mathrm{C}, 5 \mathrm{~min}\right)$, hybridisation $\left(36^{\circ} \mathrm{C}, 4 \mathrm{~min}\right)$ and elongation $\left(72^{\circ} \mathrm{C}, 2 \mathrm{~min}\right)$ step followed by 44 cycles of $95^{\circ} \mathrm{C}$ for $15 \mathrm{~s}, 36^{\circ} \mathrm{C}$ for $45 \mathrm{~s}$ and $72{ }^{\circ} \mathrm{C}$ for $1.5 \mathrm{~min}$ finalised by an elongation step at $72{ }^{\circ} \mathrm{C}$ for $10 \mathrm{~min}$. Amplification reactions were performed in a $50 \mu \mathrm{l}$ reaction volume containing $1 \times$ PCR buffer Roche, 0.2 $\mathrm{mM}$ dNTP, $3 \mathrm{mM} \mathrm{MgCl}_{2}, 0.8 \mu \mathrm{M}$ RAPD primer, 1 U Taq DNA polymerase (Roche, Bazel, Switzerland) and $100 \mathrm{ng}$ of purified genomic DNA. Both extremities of a fragment from strain K DNA amplified with OPN 13, were sequenced (T7 Sequencing kit, Amersham Bioscience, Uppsala, Sweden).

Six primers were designed (Fig. 1), one resulting from the elongation of OPN 13 primer (U1, 5'AGCGTCACTCTTAGATTCAAAAGATT-3')

and the others being homologous to internal sequences of the specific RAPD fragment (K2, 5'-CCTGGCCCTAATTCTTCTCTTGTC-3'; U2, 5'-TTTGTTACCAAGCTAGAGCCATTTT-3'; U3， 5'-ATGCTCCTTTATCCTTATTGGCTGT3'; U4, 5'-GTGTTTGTTACCAAGCTAGAGCC-3'; K1， 5'-AGGAAGAAGGATGGAAAGAATGAGG-3').

Five primer couples (U1/U2, U1/U3, U1/U4, $\mathrm{U} 1 / \mathrm{K} 2$ and $\mathrm{K} 1 / \mathrm{K} 2$ ) were tested on the total yeast collection under optimised PCR amplification conditions $(1 \times$ PCR Buffer Roche, $0.2 \mathrm{mM}$ dNTP, $0.4 \mu \mathrm{M}$ of both primers, 1 unit of Taq DNA polymerase Roche, $50 \mathrm{ng}$ of genomic DNA in $50 \mu$ final volume). The thermal cycle consisted of an initial $5 \mathrm{~min}$ denaturation followed by 35 cycles of $95{ }^{\circ} \mathrm{C}$ for $30 \mathrm{~s}, 60{ }^{\circ} \mathrm{C}$ for $45 \mathrm{~s}, 72^{\circ} \mathrm{C}$ for 45 $\mathrm{s}$ and a final elongation $\left(72^{\circ} \mathrm{C}\right.$ for $\left.5 \mathrm{~min}\right)$. The 


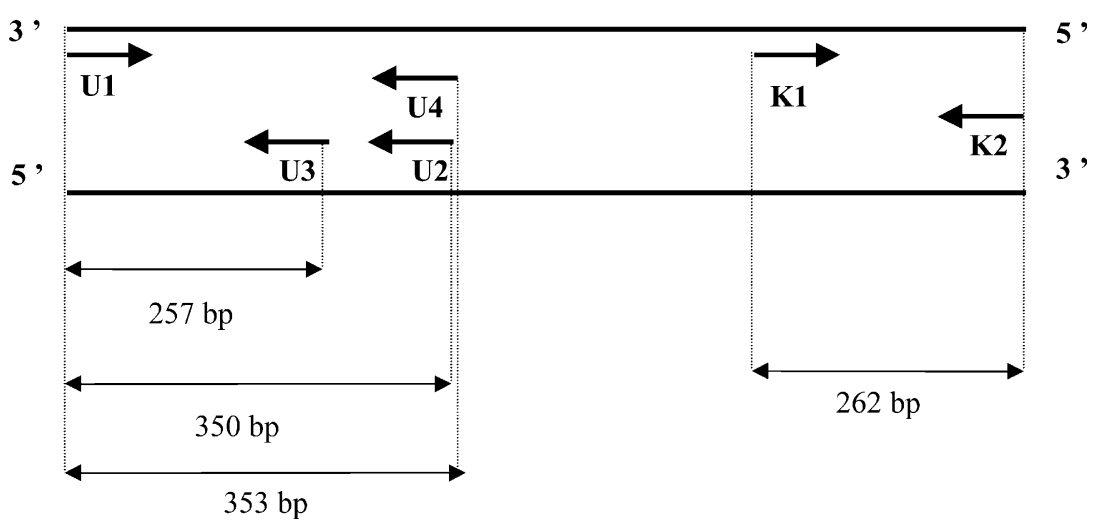

Fig. 1. Design of SCAR primers from a strain K specific fragment obtained after RAPD amplification, and expected size of the resulting SCAR fragments.

specificity of the SCAR maker, obtained with the primers $\mathrm{K} 1 / \mathrm{K} 2$ in an annealing step of $60{ }^{\circ} \mathrm{C}$ for 45 $\mathrm{s}$, was confirmed by Southern blot analysis with a digoxigenin-labelled SCAR probe according to the manufacturer's instructions (Roche).

\subsection{PCR amplification from yeast colonies (mixed monitoring)}

Randomly picked yeast colonies were suspended separately in $20 \mu \mathrm{l}$ Tris- $\mathrm{HCl} 10 \mathrm{mM}(\mathrm{pH} 8)$ and spun down $(5 \mathrm{~min}$ at $15700 \times \mathrm{g})$. The pellets were suspended in $20 \mu$ Lyse-N-Go (Pierce, Rockford, IL). This step was repeated and the pellets were finally suspended in $10 \mu \mathrm{l}$ Lyse-N-Go placed in a microwave for $30 \mathrm{~s}$. To complete lysis of the yeast cells the tubes were submitted to a thermal profile proposed by the manufacturer. One $\mu$ l of this suspension was added to $49 \mu \mathrm{l}$ of amplification reaction mixture containing $1 \times$ PCR buffer, 0.2 $\mathrm{mM}$ dNTP, $0.4 \mu \mathrm{M}$ primer $\mathrm{K} 1$ and $0.4 \mu \mathrm{M}$ primer $\mathrm{K} 2$, and $1 \mathrm{U}$ of Taq DNA polymerase (Roche). The PCR amplification conditions consisted of an initial denaturation of $5 \mathrm{~min}$ at $95^{\circ} \mathrm{C}, 40$ cycles of 30 s at $94{ }^{\circ} \mathrm{C}, 30 \mathrm{~s}$ at $60{ }^{\circ} \mathrm{C}, 30 \mathrm{~s}$ at $72^{\circ} \mathrm{C}$ and a final extension step of $5 \mathrm{~min}$ at $72{ }^{\circ} \mathrm{C}$.

\subsection{Evaluation of the population density of strain $K$}

Fresh cells of strain K produced in Petri dishes, or a powder of this biological control agent (BCA) obtained after fermentation and drying processes by CWBI (Centre Wallon de Bio-Industrie, Liège, Belgium), were applied to apples by dipping in a suspension of water at a concentration of $10^{7}$ yeast cells per $\mathrm{ml}$ for $2 \mathrm{~min}$. Treatment took place in the presence (or absence) of beta-1,3-glucan (YGT at $0.2 \% \mathrm{w} / \mathrm{v}$, Ohly, Hamburg, Germany) and $\mathrm{CaCl}_{2}$ $(2 \% \mathrm{w} / \mathrm{v})$. The number of strain $\mathrm{K}$ cells surviving on the surface of apples was evaluated after one night of drying at ambient temperature and was estimated by dilution plating of the washing water on the semi-selective medium (HST-PDA) as described above (five apples per treatment and four repetitions by dilution plated on a Petri dish). Data were subjected to analysis of variance (SYSTAT) and means were compared by Fisher's least significant difference (LSD) test at $P=0.001$.

A minimum of $3 \%$ of the total number of colonies similar to strain $\mathrm{K}$ were submitted to a PCR test with SCAR primers $\mathrm{K} 1$ and $\mathrm{K} 2$. The percentage of colonies responding to the SCAR marker was calculated and the total cfu numbers were adjusted.

\section{Results}

\subsection{Toxicity and selectivity of the medium}

Potential toxicity of the HST-PDA medium was first assessed by directly plating $P$. anomala strain $\mathrm{K}$ on that medium in relation to the incubation time (Table 2). Similar numbers of cfu were 
Table 2

Analysis of toxicity effects of the semi-selective medium HST-PDA on the growth of $P$. anomala strain K in comparison to the PDA medium

\begin{tabular}{lllll}
\hline Media & \multicolumn{3}{l}{ Incubation Time } & \\
\cline { 2 - 5 } & 2 Days (cfu/dish) & 3 Days (cfu/dish) & 4 Days (cfu/dish) & 7 Days (cfu/dish) \\
\hline PDA & $125 \pm 14$ & $126 \pm 13$ & $126 \pm 13$ & $126 \pm 13$ \\
HST-PDA & $133 \pm 6$ & $140 \pm 5$ & $140 \pm 5$ & $140 \pm 5$ \\
\hline
\end{tabular}

Colony forming unit means were calculated from eight replicates after 2, 3, 4 and 7 days of incubation at $25^{\circ} \mathrm{C}$. Data are accompanied by standard errors.

observed on PDA and HST-PDA media whatever the incubation time. No delayed colony development was observed on HST-PDA between 2 and 7 days of incubation at $25^{\circ} \mathrm{C}$.

Toxicity of the HST-PDA medium was also evaluated in relation to the survival of strain $\mathrm{K}$ on the surface of apples stored in a cold room (Table $3)$. The population density of strain $\mathrm{K}$ on treated apples reached a level of $1.2 \times 10^{4} \mathrm{cfu} / \mathrm{cm}^{2} \mathrm{im}$ mediately after treatment on both media.

In comparison with the population level before storage, a decline of 60 and $50 \%$ was observed after 2 weeks of cold storage, with population densities of $4.6 \times 10^{3}$ and $6.1 \times 10^{3} \mathrm{cfu} / \mathrm{cm}^{2}$ for PDA and HST-PDA respectively. After 58 days of cold storage, population densities were similar to that after 14 days of storage for PDA. On semiselective medium the population densities of strain $\mathrm{K}$ continued to decline and reached a level of $3 \times$ $10^{3} \mathrm{cfu} / \mathrm{cm}^{2}$.

On untreated apples, population densities of white yeast never exceeded $1.5 \times 10^{3} \mathrm{cfu} / \mathrm{cm}^{2}$ on PDA and $1.8 \times 10^{2} \mathrm{cfu} / \mathrm{cm}^{2}$ on HST-PDA media before storage and declined to zero after 58 days of cold storage.
During this experiment, the efficiency of the protocol applied to recover strain $\mathrm{K}$ cells from apple surface was also evaluated. A recovery yield of more than $99 \%$ was observed for each strain Ktreated apple.

Selectivity of the medium was evaluated by observation of natural occurring microorganisms (Fig. 2) which were able to grow on both media. While the PDA medium was covered with yeast, mycelial fungi and bacteria, the HST-PDA medium only showed the development of some (less than 10) filamentous white colonies clearly morphologically different from strain $\mathrm{K}$, and a few yellow colonies of bacteria.

\subsection{Development of a strain $K$ specific $S C A R$ primer}

The RAPD patterns of ten strains of $P$. anomala (Table 1) were compared with the pattern of strain K. RAPD amplification with primer OPN13 produced a reproducible fragment of about 2000 $\mathrm{bp}$, which was specific for strain $\mathrm{K}$. The fragment could be amplified successfully for the sole strain $\mathrm{K}$ with the primers $\mathrm{U} 1$ and $\mathrm{K} 2$, designed at the

Table 3

Analysis of toxicity level of the semi-selective medium HST-PDA in comparison to the PDA medium on P. anomala strain K from apples

\begin{tabular}{|c|c|c|c|c|c|c|}
\hline \multirow[t]{2}{*}{ Media } & \multicolumn{2}{|c|}{ Before storage $\left(\mathrm{cfu} / \mathrm{cm}^{2}\right)$} & \multicolumn{2}{|c|}{14 Days after storage $\left(\mathrm{cfu} / \mathrm{cm}^{2}\right)$} & \multicolumn{2}{|c|}{58 Days after storage $\left(\mathrm{cfu} / \mathrm{cm}^{2}\right)$} \\
\hline & Untreated & Treated & Untreated & Treated & Untreated & Treated \\
\hline $\begin{array}{l}\text { PDA } \\
\text { HST-PDA }\end{array}$ & $\begin{array}{l}1.5 \times 10^{3} \pm 4.4 \times 10^{2} \\
1.8 \times 10^{2} \pm 7.3 \times 10^{1}\end{array}$ & $\begin{array}{l}1.2 \times 10^{4} \pm 1.47 \times 10^{3} \\
1.2 \times 10^{4} \pm 1.20 \times 10^{3}\end{array}$ & $\begin{array}{l}0.0 \pm 0.00 \\
9.0 \times 10^{1} \pm 0.00\end{array}$ & $\begin{array}{l}4.6 \times 10^{3} \pm 7.36 \times 10^{2} \\
6.1 \times 10^{3} \pm 1.01 \times 10^{3}\end{array}$ & $\begin{array}{l}0.0 \pm 0.00 \\
0.0 \pm 0.00\end{array}$ & $\begin{array}{l}4.97 \times 10^{3} \pm 6.44 \times 10^{2} \\
2.6 \times 10^{3} \pm 9.38 \times 10^{2}\end{array}$ \\
\hline
\end{tabular}

Yeast cells were recovered from the (un)treated apples after 1 day of incubation at ambient temperature and after 14 and 58 days of cold storage $\left(4{ }^{\circ} \mathrm{C}\right)$. Colony forming unit means were calculated from five replicates. Data are accompanied by standard errors. 


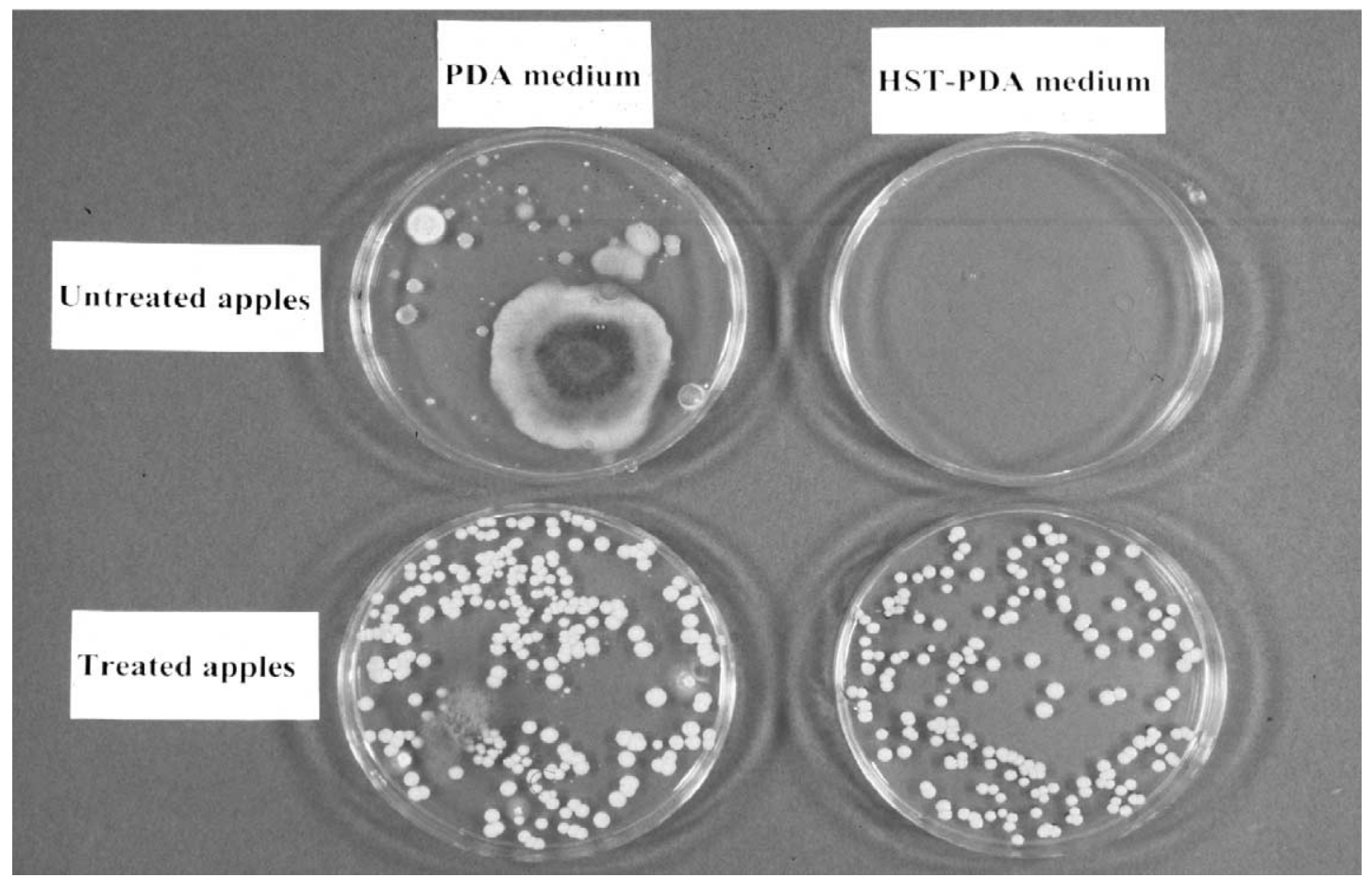

Fig. 2. Qualitative assessment of the selectivity of HST-PDA medium by comparison of natural occurring microorganisms grown on PDA and HST-PDA after plating of washings of KPB buffer from surfaces of untreated and treated apples by dipping in a water suspension containing $10^{7} \mathrm{cfu} / \mathrm{ml}$ of strain $\mathrm{K}$ and $0.85 \%$ of $\mathrm{NaCl}$ during $2 \mathrm{~min}$.

extremities of the cloned fragment sequence (data not shown). To obtain a shorter SCAR fragment, internally chosen primers were associated with one of the primers $\mathrm{U} 1$ or $\mathrm{K} 2$. In comparison to 30 yeast strains, including 21 strains of $P$. anomala, the specificity for strain $\mathrm{K}$ was obtained with the primers $\mathrm{K} 1$ and $\mathrm{K} 2$ which amplified a marker of 262 bp (Fig. 3a, c, d). This specificity was confirmed by Southern blot analysis as shown in Fig. 3b. In contrast, amplification with the primer couples U1/U2, U1/U3 and U1/U4 lost specificity for strain $\mathrm{K}$.

\subsection{Monitoring population dynamics on the surface of strain K-treated apples: effect of the formulation}

In order to evaluate population dynamics of strain $\mathrm{K}$ in relation to its mode of production and formulation, apples were treated with strain $\mathrm{K}$ produced in a bioreactor and formulated as a powder, or with strain K cultivated in Petri dishes. The treatments took place in the presence or in absence of additives previously identified as stimulants of the protective activity $\left(\mathrm{CaCl}_{2}\right.$ and $\mathrm{B}$ 1,3-glucan) (Jijakli et al., 2002).

The population densities (Fig. 4) reached similar levels of $1.1 \times 10^{4}$ and $0.7 \times 10^{4} \mathrm{cfu} / \mathrm{cm}^{2}$ on apples, $24 \mathrm{~h}$ after treatment with the powder formulation, without and with the stimulating agents, respectively. In the case of treatments with yeast cells produced in Petri dishes, population levels increased from $6.7 \times 10^{2}$ to $0.7 \times 10^{4} \mathrm{cfu} / \mathrm{cm}^{2}$ when the stimulating agents were added. One week later, population densities decreased between 3- and 8fold whatever the treatment.

Whatever the incubation period of the apples, a highly significantly $(P<0.001)$ lower population level was observed upon treatment of apples with 
(a)

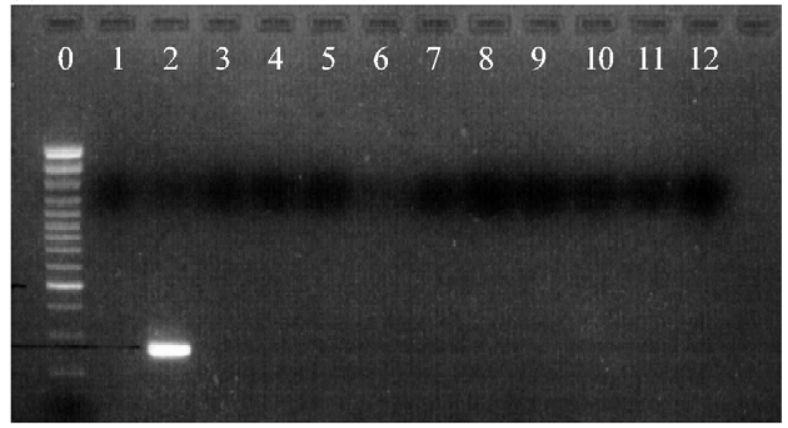

(c)

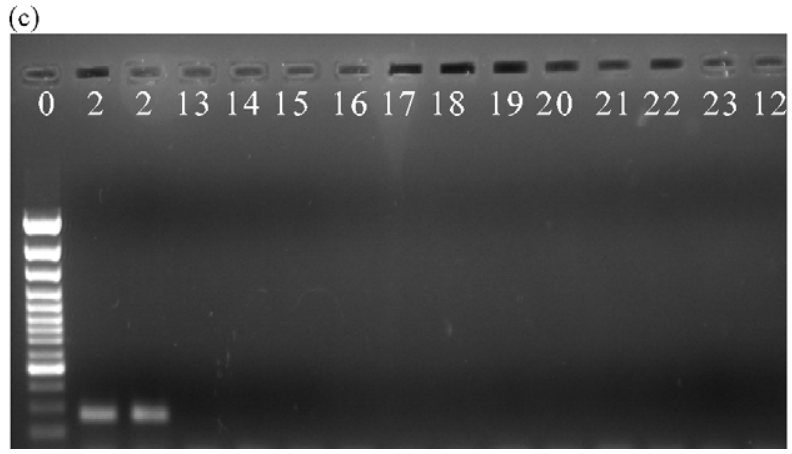

(b)

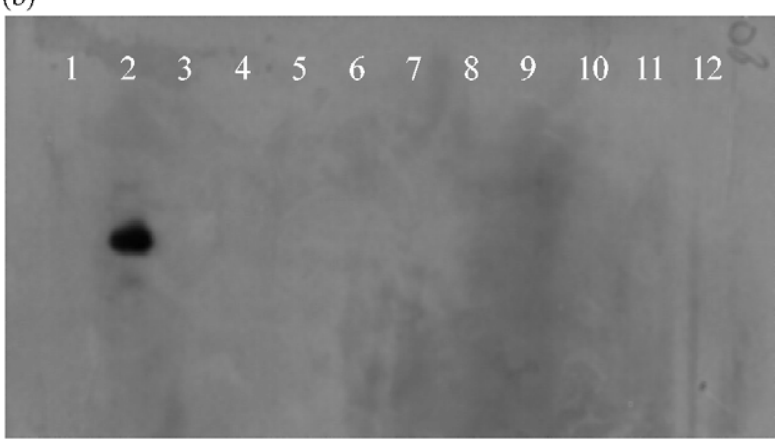

(d)

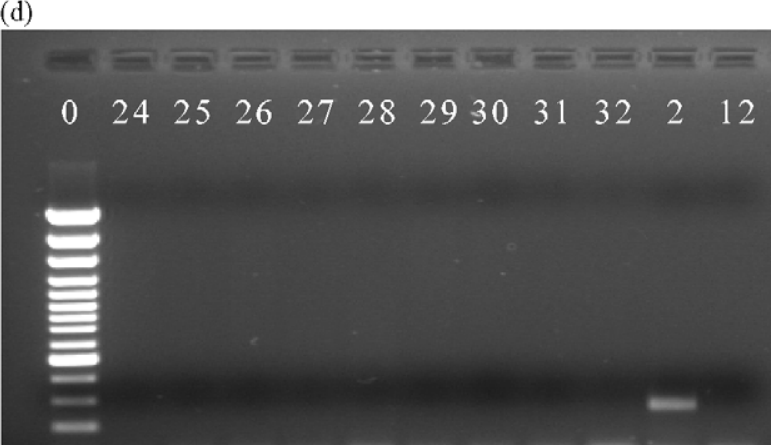

Fig. 3. PCR with the SCAR primers K1 and K2 on genomic DNA of $P$. anomala strains H-1 (1), K (2), MUCL 29421 (3), MUCL 29422 (4), $\mathrm{MUCL}_{29423}$ (5), $\mathrm{MUCL}_{27729}$ (6), $\mathrm{MUCL}_{27753}$ (7), $\mathrm{MUCL}_{28480}$ (8), MUCL 30384 (9), MUCL 20294 (10), HU-1 (11), J121 (13), J375 (14), J376 (15), J377 (16), J378 (17), J379 (18), J380 (19), J381 (20), J382 (21), J383 (22), J384 (23); C. oleophila strains O (24), CBS4731 (25), I-182 (26); C. sake strains CBS 159 (27), CBS2882 (28); D. hansenii MUCL29030 (29), MUCL29907 (30); S. cerevisiae P4-1 (31), 382 (32); PCR negative control (12); GeneRuler ${ }^{\mathrm{TM}} 100 \mathrm{pb}$ DNA Ladder Plus; MBI Fermentas (0). PCR products were visualised with ethydium bromide (a), (c) and (d) or by Southern blot analysis with a digoxigenin-labelled SCAR probe (b) as exemplified for strains number $1-11$.

strain $\mathrm{K}$ cells produced in Petri dishes in the absence of $\mathrm{CaCl}_{2}$ and $\mathrm{B}-1,3$-glucan in comparison with the three other treatments.

The percentages of the yeast identified as being $P$. anomala strain $\mathrm{K}$ by means of the specific DNA marker, reached values of between 91 and 100\% (Fig. 4).

For both treatments with strain K (powder and fresh cells), very similar population densities were obtained in the presence of $\mathrm{CaCl}_{2}$ and $\beta$-1,3-glucan with or without verifying the identity of colonies, using SCAR primers. For treatment with strain K cells produced in Petri dishes in the absence of $\mathrm{CaCl}_{2}$ and $\mathrm{B}$-1,3-glucan, $91 \%$ of the counted cfu were identified by PCR as strain K. Consequently, the pronounced and significant difference between this treatment and the other treatments was accentuated after PCR identification of colony forming units.

\section{Discussion}

The main significance of this work is the development of a monitoring method for the BCA $P$. anomala strain $\mathrm{K}$ that enables its specific identification by means of a natural DNA marker and its quantification based on dilution plating on a semi-selective medium. That method takes into account the efficiency of yeast cell recovery from the apple surface and does not require a DNA extraction method before PCR amplification.

Field and postharvest application of $P$. anomala strain $\mathrm{K}$, a naturally occurring microorganism on 


\section{mixed monitoring classical monitoring}

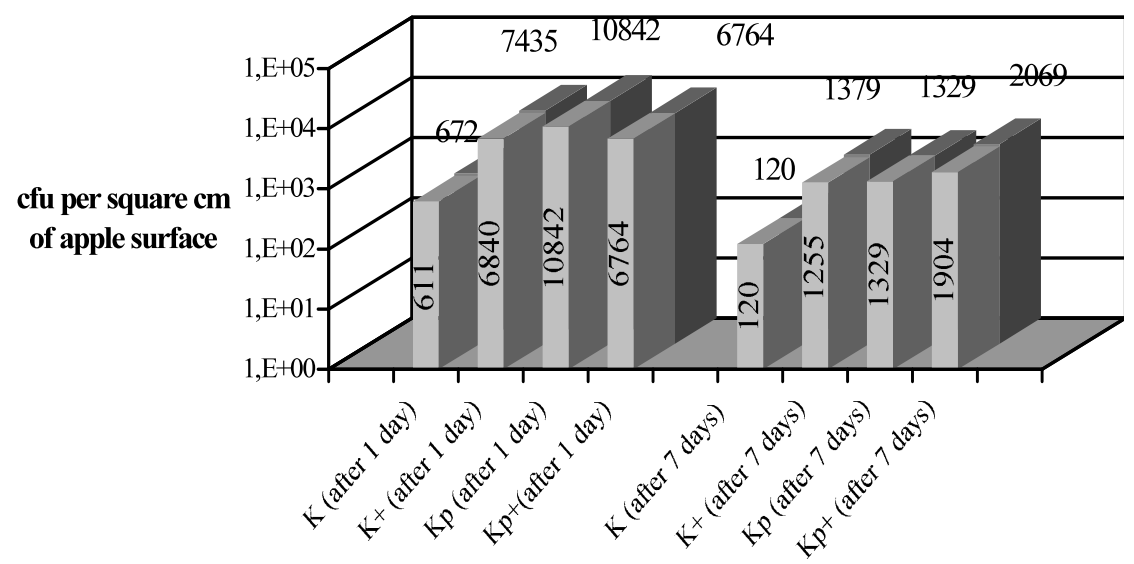

Fig. 4. Population densities $\left(\mathrm{cfu} / \mathrm{cm}^{2}\right)$ of $P$. anomala strain $\mathrm{K}$ on treated apples (treatment rate $\left.10^{7} \mathrm{cfu} / \mathrm{ml}\right)$ the day after treatment and after 7 days of cold storage. The treatment consisted of dipping in a suspension of fresh cells of strain $\mathrm{K}$ recovered from Petri dishes ( $\mathrm{K}$ and $\mathrm{K}+$ ) and of a powder of strain $\mathrm{K}$ produced in mass $(\mathrm{Kp}$ and $\mathrm{Kp}+)$ without and with $(+)$ the stimulating agents glucan and $\mathrm{CaCl}_{2}$. Population densities were monitored upon dilution plating on the semi-selective medium (classical monitoring) followed by identification of cfu by PCR with the SCAR primers K1 and K2 (mixed monitoring).

apple surfaces, could be potentially used for postharvest protection of apples against grey and blue molds. In laboratory conditions, up to $90 \%$ of the protective activity could be obtained on artificially infected apples previously treated with strain $\mathrm{K}$ by dipping. The development of a monitoring method for tracking the population dynamics of the BCA P. anomala strain $\mathrm{K}$ on the surface of apples is of particular importance because the protective effect of the yeast is closely related to its colonisation (Jijakli et al., 1999).

The classical method for quantification of the amount of a particular BCA in an environment consists in counting colony forming units on a Petri dish on a selective or semi-selective medium (Leibniger et al., 1997; Lima et al., 1999; Johnson et al., 2000; Usall et al., 2001). This method has the advantage that only living micro-organisms are quantified. The first step in a monitoring procedure of a BCA on fruit is the recovery of these microorganisms from the fruit surface. Although washing fruit in a phosphate buffer has already been used by several researchers (Chand-Goyal et al., 1998; Usall et al., 2001), the efficiency of microorganism recovery was not evaluated. We standardised a washing procedure that allowed recovery of more than $99 \%$ of yeast cells from the treated apple surface.

The semi-selective medium (HST-PDA) developed in this study contained three fungicides (thiram, carbendazim, diethofencarb) and one antibiotic (hygromycin B) and does not appear to have any toxic effect against strain K. However, this semi-selective medium did not permit an unambiguous identification of either the species $P$. anomala or the strain $\mathrm{K}$ according to its morphological characteristics. Indeed other white yeasts such as $C$. oleophila, $C$. sake, D. hansenii and $S$. cerevisiae are morphologically similar to $P$. anomala strain $\mathrm{K}$ and were also able to grow on the semi-selective medium (data not shown). To overcome this lack of specificity, a natural molecular marker for the sole strain $\mathrm{K}$ of $P$. anomala was identified. The RAPD approach proved to be a valuable fingerprinting method for identification of a DNA polymorphism for the sole strain K among ten other isolates of $P$. anomala. Indeed, a strain-specific RAPD fragment of $2 \mathrm{~kb}$ could be obtained upon non-stringent PCR amplification with the decamer primer OPN 13. This DNA marker could be reproduced upon amplification with U1 primer, an elongated RAPD primer, and 
K2 primer localised close to the other extremity. To obtain a smaller DNA marker, several internal primer couples were tested for their specificity. Only the primer couple $\mathrm{K} 1$ and $\mathrm{K} 2$ amplified a strain $\mathrm{K}$ specific DNA fragment among a collection of 21 strains of the same species. In addition, specificity of these SCAR primers for the sole strain $\mathrm{K}$ was equally validated with template DNA from seven strains commonly isolated from apple surface (C. oleophila, C. sake, D. hansenii) and two strains of $S$. cerevisiae. In comparison with the RAPD marker, the SCAR marker allowed the identification of strain $\mathrm{K}$ in a more rapid and reproducible way. A similar approach was also successfully used for the specific detection of Aureobasidium pullulans L47 (Schena et al., 2002)

Monitoring methods combining plating in Petri dish with a RAPD or PCR screening on randomly chosen colonies have already been described using classical DNA extraction procedures before PCR amplification (Chand-Goyal et al., 1998; Abassi et al., 1999). In contrast, liberated DNA in a cell lysate suspension of the yeast strain $\mathrm{K}$ was directly used for amplification without preliminary DNA extraction. This step facilitated and speeded up the monitoring procedure, allowing routine application.

This mixed monitoring method was then applied on apples treated with strain $\mathrm{K}$ produced in Petri dishes or in bio-reactor with or without additives previously identified to enhance the strain $\mathrm{K}$ efficacy against B. cinerea (Jijakli et al., 2002). A stimulating effect upon addition of glucan and $\mathrm{CaCl}_{2}$ was only observed for apple treatment with fresh cells produced on Petri dishes. The mechanisms of the effect of these agents remain unclear. However, a general tendency was observed: whatever the treatment, population densities diminished 1 week after application in cold storage conditions. The population density of yeast colonies established on strain K-treated apples diminished also after 2-months period of cold storage, but remained higher than $3 \times 10^{3} \mathrm{cfu} / \mathrm{cm}^{2}$. This demonstrates the BCA's ability to survive under storage conditions, which could be of interest for long-term biological control efficacy.

The mixed monitoring method was compared with the classical plating method. The percentages of white colonies identified as strain $\mathrm{K}$ with the use of the specific SCAR marker were high (between 91 and $100 \%$ ). Consequently, this correction did not lead to severe changes in the dilution plating results. However, molecular identification of the colony forming units gives a more valuable result in terms of specificity. Some of the white yeast colonies did not respond to the SCAR primers and were, therefore, considered as contaminants. These contaminating white yeast naturally present on the surface of apples are not necessarily distributed in a homogeneous manner, neither in terms of spatial distribution nor in terms of time or survival, which would falsify population studies of the BCA if monitoring was exclusively based upon morphological characteristics on a semi-selective medium. Considering the number of strains tested for the specificity of the SCAR marker and the low ratio (less than $1.5 \%$, Table 3 ) between the number of natural epiphytic yeast cells morphologically similar to strain $\mathrm{K}$ and the number of strain $\mathrm{K}$ cells on the apple surface after its application, the probability of being able to amplify the strain K SCAR marker from white colonies grown on a semiselective medium, which do not belong to strain $\mathrm{K}$, is very low. Therefore, this monitoring method will be useful to evaluate the population dynamics of strain $\mathrm{K}$ after its application on apples under various laboratory and practical conditions. Moreover, this method can be part of a quality control procedure during production and formulation of strain $\mathrm{K}$.

\section{Acknowledgements}

This work was supported by DGTRE of Walloon Region. We thank Coralie Bastin and Carole Kubjak for their technical assistance.

\section{References}

Abassi, P.A., Miller, S.A., Meulia, T., Hoitink, H., Kim, J.-M., 1999. Precise detection and tracing of Trichoderma hamatum 382 in compost-amended potting mixes by using molecular markers. Appl. Environ. Microbiol. 65, 54215426. 
Arisan-Atac, I., Heidenreich, E., Kubicek, E.H.A., 1995. Randomly amplified polymorphic DNA fingerprinting identifies subgroups of Trichoderma viride and other Trichoderma spp. capable of chestnut blight biocontrol. FEMS Microbiol. Lett. 126, 249-256.

Ausubel, F.M., Brent, R., Kingston, R.E., Moore, D.E., Seidman, J.G., Smith, J.A., Struhl, K., 1987. Preparation of yeast DNA. In: Current Protocols in Molecular Biology, vol. 2. Wiley, New York, p. 13.11.2.

Batinic, T., Schmitt, J., Schultz, U.M., Werner, D., 1998. Construction of RAPD-generated DNA probes for the quantification of Bacillus subtilis FZBC and the evaluation of its biocontrol efficiency in the system Cucumis sativus Pythium ultimum. J. Plant Dis. Protection 105, 168-180.

Chand-Goyal, T., Eckert, J.W., Droby, S., Atkinson, K., 1998. A method for studying the population dynamics of Candida oleophila on oranges in the grove, using a selective isolation medium and PCR technique. Microbiol. Res. 153, 265-270.

Chand-Goyal, T., Eckert, J.W., Droby, S., Glickmann, E., Atkinson, K., 1999. Transformation of Candida oleophila and survival of a transformant on orange fruit under field conditions. Curr. Genet. 35, 51-57.

Franclet, J., 1994. Enquête ANPP-Maladies de conservation des pommes. Arboric Fruit 473, 24-26.

Grevesse, C., Jijakli, M.H., Duterme, O., Colinet, D., Lepoivre, P., 1998. Preliminary study of exo- $\beta-1,3-$ Glucanase encoding genes in relation to the protective activity of Pichia anomala (strain K) against Botrytis cinerea on postharvest apples. In: Biological Control of Fungal and Bacterial Plant Pathogens. IOBC/WPRS Bull. 21, 81-89.

Jijakli, M.H., Lepoivre, P., 1993. Biological control of postharvest Botrytis cinerea and Penicillium on apples. In: Fokkema, N.J., Köhl, J., Elad, Y. (Eds.), Biological Control of Foliar and Post-Harvest Diseases. IOBC/WPRS Bull. 16, $106-110$.

Jijakli, M.H., Lepoivre, P., 1998. Characterization of an exo- $\beta$ 1,3-glucanase produced by Pichia anomala stain K, antagonist of Botrytis cinerea on apples. Phytopathology 88, 335343.

Jijakli, M.H., Lepoivre, P., Grevesse, C., 1999. Yeast species for biocontrol of apple postharvest diseases: an encouraging case of study for practical use. In: Mukerji, K.G., Chamola,
B.P., Upadhyay, R.K. (Eds.), Biotechnological Approaches in Biocontrol of Plant Pathogens. Kluwer Academic/Plenum Publishers, New York, pp. 31-49.

Jijakli, M.H., De Clercq, D., Dickburt, C., Lepoivre, P., 2002. Pre- and post-harvest practical application of Pichia anomala strain $\mathrm{K}, \beta$-1,3-glucans and calcium chloride on apples: 2 years of monitoring and efficacy against post-harvest diseases. In: Elad, Y. (Ed.), Biological Control of Foliar and Post-Harvest Diseases. IOBC/WPRS Bull., 25, 29-32.

Johnson, K.B., Stockwell, V.O., Sawyer, T.L., Sugar, D., 2000. Assessment of environmental factors influencing growth and spread of Pantoea agglomerans on and among blossoms of pear and apple. Phytopathology 90, 1285-1294.

Leibniger, W., Breuker, B., Hahn, M., Mendgen, K., 1997. Control of postharvest pathogens and colonisation of the apple surface by antagonistic microorganisms in the field. Phytopathology 87, 1103-1110.

Lima, G., Arru, S., De Curtis, F., Arras, G., 1999. Influence of antagonist, host fruit and pathogen on the biological control of postharvest fungal diseases by yeasts. J. Ind. Microbiol. Biotechnol. 23, 223-229.

Olive, M., Bean, P., 1999. Principles and applications of methods for DNA-based typing of microbial organisms. J. Clin. Microbiol. 37, 1661-1669.

Schena, L., Sialer, M.F., Gallitelli, D., 2002. Molecular detection of strain L47 of Aureobasidium pullulans, a biocontrol agent of postharvest diseases. Plant Dis. 86, 54-60.

Thanos, M., Schönian, G., Meyer, W., Schweynoch, C., Gräser, Y., Mitchell, T.G., Presber, W., Tietz, H.-J., 1996. Rapid identification of Candida species by DNA fingerprinting with PCR. J. Clin. Microbiol. 34, 615-621.

Usall, J., Teixido, N., Torres, R., Ochoa de Eribe, X., Vinas, I., 2001. Pilot tests of Candida sake (CPA-1) applications to control postharvest blue mold on apple fruit. Postharvest Biol. Technol. 21, 147-156.

Wellings, P.W., 1996. The role of public policy in biological control: some global trends. Entomophaga 41, 435-441.

Williams, J.K.G., Kubelik, A.R., Livak, K.J., Rafalski, J.A., Tingey, S.V., 1990. DNA polymorphisms amplified by arbitrary primers are useful as genetic markers. Nucleic Acids Res. 18, 6531-6535. 